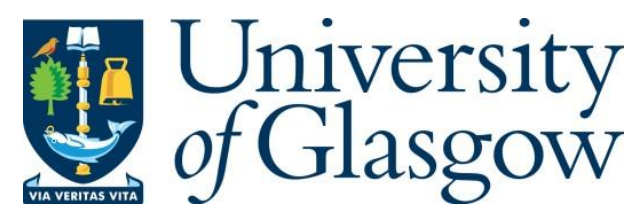

Li, Y. and McKernan, J. (2017) 'Achieved not given': human rights, critique and the need for strong foundations. International Journal of Human Rights, 21(3), pp. 252-269.

There may be differences between this version and the published version. You are advised to consult the publisher's version if you wish to cite from it.

http://eprints.gla.ac.uk/140546/

Deposited on: 15 April 2020

Enlighten - Research publications by members of the University of Glasgow http://eprints.gla.ac.uk 


\title{
'Achieved not given': Human rights, critique and the need for strong foundations
}

\author{
Yingru Li ${ }^{*}$ and John McKernan \\ Adam Smith Business School, The University of Glasgow
}

In this article we focus critically on the normative foundations of the project outlined by Benjamin Gregg in The Human Rights State (2016). In developing our analysis of Gregg's project, we consider it in context of the inspiration it draws from the work of Hannah Arendt and Jacques Rancière. We argue that Arendt does not give Gregg any robust support for his anti-foundationalism, and that Rancière's politics of dissensus makes an uneasy ally for Gregg's constructivism. We argue that we need strong moral foundations to motivate critique and ground valid construction, and that they need not draw us back into the authoritarianism so often associated with classical foundations on which human rights claims have sometimes relied. We suggest that the right kind of thin but strong moral foundations are most clearly articulated in the work of the critical theorist Rainer Forst, and that Forst's constructivism and his emphasis on dissensus makes his perspective particularly compatible with Gregg's project. In the final parts of the paper, we expose what we see as the unacknowledged normative foundations of Gregg's position. We conclude by briefly examining the practical significance of his neglect of those foundations and the moral context that are crucial for tackling the governance gap in business human rights issues.

Keywords: human rights; moral foundations; normativity; philosophy of human rights; critique; right to justification; John Ruggie; UN Guiding Principles; human rights and business

\footnotetext{
* Corresponding author. Email: Yingru.Li@glasgow.ac.uk
} 


\section{Introduction}

In his recent work Benjamin Gregg develops the idea of the human rights state ${ }^{1}$ and explores its potential to promote the free embrace of human rights. At the heart of Gregg's project is a commitment to pragmatism and normative anti-foundationalism. He holds a 'resolutely political $^{2}$ view of human rights in the sense that he sees their content and validity as being entirely socially constructed, rather than given by any pre-political authority.

We welcome the project and agree that the idea of human rights has a critical part to play in advancing social justice. We will argue, however, contrary to Gregg, that to facilitate the realisation of national and transnational justice, we need a conception of rights that has strong normative foundations, and we need to retain an appreciation of the autonomy of morality beyond politics. We will use the work of Rainer Forst, a third generation critical theorist, to help develop our argument, and to show how we can have strong foundations which do not risk plunging us back into the 'reified and ultimately authoritarian forms of thinking' ${ }^{3}$ that have all too often been associated with classical theological and metaphysical foundations. The necessary foundation, we will suggest, is in the context transcending, normative recognition of the individual as the bearer of a right to justification.

The project that Gregg advances with the idea of the human rights state is intended to contribute to the achievement of 'a realistic utopia of universal human rights' ${ }^{4}$ He makes it clear that his project is not driven by a prior commitment to any particular construal of human rights. It starts with 'the bare idea of human rights" ${ }^{5}$ as an initially quite indeterminate rhetorical conception capable of carrying different meanings. He encourages his readers to be pragmatic when imagining the content that should be given to the idea. He is motivated by how the idea can contribute to the achievement of 'desired results' ${ }^{6}$, and quite unconcerned about whether people can agree on the foundations of human rights. Whilst we will insist that we need clear, strong yet thin, moral foundations if we are to adequately interrogate our intuitions concerning 'desired results', we welcome the practical and imaginative approach that Gregg brings to the problem of human rights.

Gregg's pragmatism finds some echo in the work John Ruggie has undertaken for the United Nations on the governance of corporate behaviour in relation to human rights. In pursuit of desired results, Ruggie is prepared to break with the conceptual limits that some philosophers are inclined to place on human rights. In particular he breaks with the 'dogmas ${ }^{7}$ of statism and 
legalism: the ideas that human rights impose responsibilities primarily on states and that they need to be given effect essentially through law. In a context where the pressures of globalization have generated governance gaps ${ }^{8}$ exposing the limits to the capacity of states and law to control the activities of transnational corporations, it becomes clear for Ruggie that it is necessary to go beyond statism and legalism, to engage actors directly on the moral level. Paradoxically, Gregg's pragmatism has a curiously dogmatic dimension. He resists giving any recognition to the moral, as such, which we will contend is very much a thing of our practical being in the world. The consequence of his refusal of the moral is an unrestrained political constructivism and, an apparently related, commitment to statism and legalism. The effect is to constrain the development of his conception of the human rights 'state', the primary function of which, as he sees it, is to press for the development of law in the real nation state it is 'twinned' with.

In this article we argue that it is important that we recognise the real moral foundation of human rights, in a right to justification. We start, in the second section, by examining those aspects of Gregg's analysis that are most relevant to our argument, including the political role, foundations and the critical potential of the human rights state. In the third section, we argue that we need and can safely have stronger moral foundations than Gregg explicitly allows. In the fourth section, we expose certain implicit commitments in Gregg's thinking, the acceptance and logical extension of which would strengthen the critical potential of his position. Finally, we offer our concluding reflections on Gregg's project, and briefly illustrate the practical significance of our criticism using the issue of human rights and business. Ultimately we encourage the extension of the metaphor of the 'human rights state', beyond the state and beyond politics. We suggest that it can be, and needs to be, extended to the moral level, and to other contexts. We can imagine the metaphor being usefully stretched to encompass the 'human rights business community', and perhaps even the 'human rights corporation' as communities of human rights advocates in business contexts.

\section{Affirming human rights: Gregg's project}

Gregg rejects the classical foundations for human rights. Rather than looking to theology or metaphysics, he insists that 'human communities invent moralities'. ${ }^{9}$ He rejects the idea that our normative commitments need to be underpinned by anything outside of 'human imagination and agency ${ }^{10}$, anything beyond ourselves and our communities. For Gregg, human rights, and more generally our ideas about justice, never start out as universals. Nevertheless, whilst they must begin as constructions in particular communities we can, he 
argues, realistically hope for their eventual universal embrace. The human rights state is conceived as a device to help promote such a cosmopolitan vision. If a set of human rights does eventually attain universal purchase, on Gregg's account, they achieve no transcendence but rather simply become 'contingently and without necessity, a particularism shared by all persons, hence universally valid solely as a matter of empirical description of a historical event'. ${ }^{11}$

Gregg finds inspiration for his own vision of a human rights state that has and needs 'no foundation other than itself ${ }^{12}$, in his reading of Richard Rorty and Hannah Arendt. With Rorty, he recognises our normative commitments as a product of our community, its culture, traditions, and institutions, and as having no foundation other than the beliefs, values, goals and emotions that we share: the kind of foundation that allows us to say little more than 'We do not do this sort of thing'. ${ }^{13}$ Similarly, Gregg sees endorsement for his anti-foundational constructionist view of human rights, his 'claim that 'we' decide to give ourselves rights, and that 'we' do so mutually' ${ }^{14}$, in what he sees as Arendt's view of equality as socially constructed: 'We are not born equal; we become equal as members of a group on the strength of our decision to guarantee ourselves mutually equal rights'. ${ }^{15}$

However, as the philosophers Seyla Benhabib and Jeremy Waldron have pointed out, Arendt's decisionist position rests on unacknowledged normative foundations. Benhabib is skeptical of the suggestion that Arendt's views on equality and rights can be best understood as anti-foundationalist. She contends that, despite the absence of acknowledgement of normative justification, Arendt's view of politics and of the political is quite incomprehensible 'without a strongly grounded normative position in universalistic human rights, equality, and respect' ${ }^{16}$ She argues that Arendt's thinking is grounded in an 'anthropological universalism'17, under which human life is given under common conditions of: 'natality, plurality, labor, work, and action'. ${ }^{18}$ Benhabib sees an implicit ethical gesture in the abstraction of Arendt's approach to humanity in terms of our essential equality, our commonality, and an ethics of radical intersubjectivity and mutual respect emerging from the substance of Arendt's anthropological universalism. For Benhabib, what is missing in Arendt's work is an articulation of the link between her analysis of the human condition, her philosophical anthropology, and the ethical attitude of universal respect she is committed to.

Waldron also looks for and finds foundations in Arendt's work, and in particular in her view of human equality. As we have seen, Arendt sometimes seems to claim that equality in politics rests on nothing more than our arbitrary decision to grant a status of equality to human 
beings. However, the fact that equality is a matter of commitment, an 'ought' uncompelled by what 'is', does not mean that the position we decide to take on it has no relation to facts about human nature or the human condition: 'our value position on equality can supervene upon certain factual propositions even though it is not entailed by those propositions'. ${ }^{19}$

Waldron shows that, for Arendt, the 'ought' of equality is grounded in, supervenes on, a basic fact of the human condition, the human capacity for free action and new beginnings: Arendtian 'natality'. All human beings are born, and born equally capable of freedom, initiative, and political action. Waldron argues that Arendt's commitment to equality is no foundationless leap in the dark, it is firmly tied to her recognition of certain aspects of the way human beings are; most especially our capacity for freedom: 'the sheer capacity to begin, which animates and inspires all human activities and is the hidden source of production of all great and beautiful things'. ${ }^{20}$ Waldron wants to disassociate Arendt's position from an 'ungrounded decisionism' that leaves our commitments to equality and rights entirely without foundation, and effectively 'just something we happen to do around here'. ${ }^{21}$ Consequently, we argue, Gregg cannot safely take support from Arendt for his own foundationless constructivism. Benhabib and Waldron show that, while Arendt is inclined to claim that equality and rights are grounded in nothing more than our decision, fuller examination of her position reveals unacknowledged foundations. We will contend in a later part of this article that foundations can be found in Gregg's position, too, despite his explicit denials.

Gregg offers the notion of the human rights state as a pragmatic response to Arendt's puzzling idea of a 'right to have rights'. ${ }^{22}$ The formulation is essentially ambiguous: it can be read either as 'pointing to an irreparable groundlessness of rights'23, or to a '(r)ecovery of confidence in the idea of rational universal human rights' ${ }^{24}$ Benhabib follows the latter reading and argues that Arendt is invoking a moral claim, to the effect that 'in virtue of our humanity alone' we are 'entitled to be treated in certain ways' ${ }^{25}$ The problem, as Benhabib sees it, is that Arendt leaves the moral right without articulated foundation. Gregg, true to his decisionist interpretation of Arendt, sees no moral aspect to her formulation. He reads her claim, that the 'right to have rights or the right of every individual to belong to humanity, should be guaranteed by humanity itself ${ }^{26}$, as thoroughly political. Gregg sees Arendt as sharing his view that we can have human rights only in political community. The puzzle, for Gregg, is that if we see nation states as the communities granting rights and, in the absence of a universal political community that is able to secure human rights, the idea of a right to have right leaves us caught 
between the universal and the particular, with a "putatively universal right to a state membership that can only be a particular right' ${ }^{27}$

To solve this puzzle, Gregg argues that traditional views of the nation state should be supplemented by the idea of a human rights state offering a 'space' to reconcile universal human rights and particularistic national citizenship rights. ${ }^{28}$ Gregg's human rights states are metaphorical states wherein those whose rights are denied in real states might find their claims recognised and supported. Each nation state has its corresponding human rights state. It is a state whose members consist of human rights advocates; an imagined state that models what a nation state could be if it fully embraced and expressed the idea of human rights in its political self-understanding and its law. The ultimate goal of a human rights state is to transform domestic law so that human rights will be accorded by the state to all, irrespective of their citizenship. It formulates a 'counterfactual'29 against a real state that refuses to adequately recognise human rights. It constitutes a "critical moral standard"30 against which the human rights performance of a nation state can be measured.

The human rights state replaces the exclusionary logic of the nation state with a logic of inclusion. It recognises all human beings, whether citizens or not, as bearers of human rights, such that from 'the standpoint of the human rights state, all are legally equal with respect to state-based human rights'. ${ }^{31}$ Human rights take their full force when backed by law, and generally only nation states make and enforce law. The human rights state does not replace the nation state but rather acts as a provocation to it, challenging it to recognise and respond to the human rights, as cosmopolitan demands, that the participants in the human rights states have claimed for themselves and constructed together in community.

Gregg's formulation of the human rights state as a politics of contestatory cosmopolitanism, as challenge to, and disruption of, an unsatisfactory nation state and social order, takes its 'cue' ${ }^{32}$ from Jacques Rancière's politics of dissensus. Politics for Rancière consists in action that separates 'the community from itself' 3 , from its own consensus, by the staging of scenes of dissensus. Rancière rejects the choice he sees Arendt as offering us between a view of human rights as the rights that states give citizens or as the rights of the rightless. He takes a dynamic view of human rights in which they come alive in the dialectic of political struggle: in 'the back-and-forth movement between the initial inscription of the right and the dissensual stage on which it is put to the test' ${ }^{34}$ Human rights become 'the rights of those who make something of that inscription, ${ }^{35}$, using and proving the power of the 
inscription. For Rancière 'the only universal in politics is equality' 36 ; his politics is always grounded in a universal claim to equality that carries with it a right, prior to any other human rights, to stage dissensus and oppose exclusion.

Gregg's conception of the human rights state is an interesting attempt to envisage and facilitate the staging of dissensus, the separation of a community from itself. Gregg sees this political moment emerging in the separation of the human rights state from itself in the form of the nation state. He understands the political role of human rights inscriptions in much the same way as Rancière does. He recognises that 'human rights are what one claims, not simply what one has ${ }^{37}$, and sees the political significance of 'making something of' rights inscriptions and of institutionalizing human rights in such a way that they 'exceed that institutionalization',38 and are capable of supporting new and as yet unforeseen claims and resistances. Gregg sees himself as extending Rancière's conception of dissensus which he considers overly bound to particular nation states. ${ }^{39}$ With the idea of the human rights state he aims to deterritorialise dissensus and provide a new source of rights inscriptions, self-authored by individuals and groups, available to be made use of.

Gregg's idea of the human rights state complements Rancière's politics in various ways. Ultimately however it seems that Gregg's position is fundamentally ill-suited to deliver the dissensus he recognises as necessary, and is incompatible with Rancière's politics. Rancière aims precisely at the disruption of the social order, the disruption of the community and its norms. For Rancière the challenge comes 'from the opening of the community to its outside" from the excluded, 'those who have no part'. ${ }^{41}$ The politics of dissensus needs to be imagined as the working through many local and partial struggles of outsiders, of the marginalised and excluded. It cannot be understood in terms of 'utopian visions' or primarily as the 'task of those on the inside'. ${ }^{42}$ Gregg's project of social construction, with advocates working towards the progressive realisation of a guiding utopian vision of universal human rights, is almost the polar opposite, in spirit, of dissensual politics. Gregg's political project aims not at dissensus but at agreement and the ever fuller free embrace of human rights. The project is essentially affirmative rather than disruptive. It is the project for the construction of a social order of respect for human rights. The outside is to be progressively socialised, brought within this social order and enabled to assert itself in terms of the language of the envisioned utopian social order of human rights. 
Inspired by Jacques Rancière's work, Gregg imagines the politics he offers as 'opening up a dispute ${ }^{43}$, that is "politics as robust openness to possibilities never before realised" ${ }^{24}$ and capable of transforming the nation state. This radical ideal runs up against the fact of his insistence that there can be no normative foundations beyond the community itself; not even in a dissensual claim to a transcendent equality. For Gregg, even the idea of equality is a socially constructed product of particular social orders and their hierarchies. Given that, for Gregg, there is no external point from which to challenge the community, any dispute opened up can only be a dispute within the social order. It is difficult to see where Gregg's vision really makes room for the staging of politics understood as the clash of the logics of hierarchy and of equality.

Gregg argues for a localist approach such that human rights are valid only, at least initially, for the community where they are embraced. Gregg may explicitly advocate that we work from the bottom-up, always starting from the particular, the local, but in fact his emphasis is on the big socio-cultural project. He therefore tends to 'sideline those politically struggling for their own rights' ${ }^{45}$ The local is to be socialised towards a preset target of a fuller, and ultimately universal, embrace of human rights. Gregg sees the full potential of human rights as political constructions as emerging only in the forging and reforging of agreement, through which we may obtain 'a nonidiosyncratic perspective' on human rights; a perspective that can claim to be 'true or valid because it is held consensually'. ${ }^{46}$ This faux 'universal', built from the bottom-up through processes of socialization, and with a claim to 'truth' behind it, is surely exactly the kind of order that Rancière's politics defines itself against.

In the following section we will take up and develop certain of the themes introduced above. Gregg's focus on dissensus is vitally important: we agree that politics must have an antagonistic moment in which oppression and exclusion are disclosed and 'wrongs ${ }^{47}$ wrestled over. As the critical theorist Rainer Forst puts it, in terms that Rancière would surely approve: 'The victim of injustice is not primarily the person who lacks certain goods, but the one who does not 'count' in the production and distribution of goods' ${ }^{48}$ Forst makes dissensus the point of departure for his constructivist approach to politics and human rights, which has considerable compatibility with Gregg's project and ultimately more to offer than Rancière.

We return to Gregg's theme of inclusion and the puzzle of the 'right to have rights' which we understand as essentially 'the right to political inclusion'49; the right to have an 'opinion' that counts. This right to inclusion is the most fundamental because on it depends other rights 
and the right to participate in their construction. We see this basic Arendtian right, in Forst's terms as 'expressing the right to codetermine one's polity in an autonomous manner' ${ }^{50}$, and argue that it is best understood in terms as a right to justification.

Finally, we will take up again the question of normative foundations. We see Gregg's refusal of such foundations as the defining weakness of his project. We will argue that we can have strong moral foundations, that will not draw us down authoritarian paths, and that we need them to enable critique and to motivate dissensus and justified construction. As explained above, those foundations are not clearly articulated in Arendt's work, but she does - in our view, correctly - locate their ground in the human condition. Retaining inspiration from Arendt, we turn again to the critical theory of Rainer Forst for a more adequate articulation of the grounding of rights. In Forst's analysis we see the lacunae in Arendt's work being overcome in the reconstruction of the right to justification and in the confrontation of 'the 'ultimate' normative question of how a duty to justify can itself be justified' ${ }^{51}$

\section{From affirmation to critique}

On Forst's reorientation of critical theory, dissensus, challenge to the normative order, is at the heart of every political struggle the primary focus and starting point of practical reason. For Forst human rights claims have their essential origins in contexts of dissent and conflict: 'the demand for human rights arises within social conflicts in which a justification for existing structures that are perceived to be unjust is called for in a particular way'. ${ }^{52} \mathrm{He}$ argues that before any demand for particular rights is raised, a basic human right is claimed: the 'right to justification', that is 'the right to be respected as a moral person who is autonomous at least in the sense that he or she must not be treated in any manner for which adequate reasons cannot be provided'. ${ }^{53}$ The demand that justifying reasons be given for the actions, rules, and structures that we are subject to, and that we not be treated in a way that cannot be adequately justified, is for Forst an absolutely fundamental and intersubjectively binding claim. It is the basic right because, although not a particular established concrete human right, it is rather 'the basis of the justification of concrete rights'.54

Every social order is essentially a normative order that may be subject to critique involving a test of the real order, and its claims to justification, against established ideals. Each of Gregg's human rights states represents such an ideal standard against which a nation state might be measured and judged. For Gregg, the critique is never 'transcendent' but, taking inspiration 
from the ideas of George Herbert $\mathrm{Mead}^{55}$, he suggests that each socially constructed particularism, each community, can take up an 'objectivating stance' towards others and in the process relativise its own view and identify and embrace a shared, overlapping, thin moral minimum. The foundation is always the particular and the process essentially immanent: 'it is work within a tradition even while reaching beyond it through self-interpretation, indeed through a kind of immanent critique'. ${ }^{56}$ The process allows a community to test its thick particular norms against emerging norms that are somewhat more generalizable and widely shareable, and ideally universally sharable. It allows some refinement of local norms through such a test, potentially exposing and helping a community to resolve contradictions and tensions within its thick, local and particular, normative scheme. Gregg's vision is of a spreading embrace of human rights thick and thin, moving 'internally, community by community'. 57

Forst argues that we need more than immanent critique. We need a way of challenging in a more fundamental way what is accepted within a community as justifiable; including a more radical way of challenging the social order, the order of justification itself, even as it appears in terms of its best 'self-interpretation'. ${ }^{58}$ The enterprise of critical examination of the order of justification needs, if it is to have real purchase, criteria that somehow 'transcend' the prevailing discourse and order of justification. Of course, dominant discourses and orders often arise in, and perpetuate conditions of, systematic inequality of power and distorted communication. It may not always be possible for participants to gain the critical distance which makes critique possible. Nevertheless, Forst argues that 'critique can develop a force that transcends existing discourses and asks what free and equal persons would agree to if they were to judge their social and political situation reflexively, without being constrained by the very power that is the object of reflection'. ${ }^{59}$

While Gregg resolutely refuses ultimate foundations, Forst insists that even in these postmetaphysical times we cannot do without moral foundations; the final 'foundation of constructivism cannot itself be constructed' ${ }^{60}$ His constructivist conception of justice and human rights rest ultimately on 'a moral principle of justification, that is, on the substantive individual moral right to justification' ${ }^{61}$ The principle of justification, as final indispensable foundation, is not constructed but rather 'reconstructed in an analysis of our normative world' ${ }^{62}$ The principle of justification, in Forst, is the foundation for valid construction, but 
more it is the context transcendent foundation for challenge to what has been constructed the existing normative order; it is the ultimate basis for critique and dissensus.

The fundamental principle of practical reason, the principle of justification, is that 'normative answers to practical questions are to be justified in precisely the manner referred to by their validity claims'. ${ }^{63}$ The moral context of practical justification, 'is distinguished by its requiring reasons for actions, or for action-legitimating norms, adherence to which every moral person can demand from every other, even when those affected share no more closely identifiable ethical or political context' ${ }^{64}$ The categorical validity claims of moral norms, the claim that every person has an unconditional duty to adhere to the norm, effectively makes the claim that no one has good reason to violate the norm, that is, that it has reciprocal and general validity.

Forst argues that, when we take this recursive step, we find that the redemption of such validity claims requires discursive procedures through which all subject to the norm can assess the justification of its validity claim in terms of the morally decisive criteria of reciprocity and generality. Justified moral action and action legitimating norms must then be reciprocally and generally non-rejectable. The principle of justification entails the claim that every individual has a right to justification. For Forst, the first claim of justice is that all are equally entitled to offer and challenge justifications; everyone 'counts', and he sees this as simply the best way we have of expressing the Kantian categorical imperative, essentially what it means to respect people as 'ends in themselves'. ${ }^{65}$ This single, and essentially universal, right to justification becomes the foundation for the construction of social and political justice.

This, of course, raises the question of how a duty to respect others as ends, as justificatory equals, as persons who 'count" ${ }^{66}$, is justified; how we justify 'the presupposition of the equality of anyone and everyone, ${ }^{67}$ that drives politics as dissensus and subversion. From the perspective of Gregg's social construction, no propositions can have a priori universal validity. For Gregg, the claim that 'all persons are ends in themselves' is just not 'immediately defensible'. ${ }^{68}$ Gregg may fight to defend the claim that autonomous persons should be treated as 'ends in themselves', but is unprepared to see it as anything other than an essentially contingent social construct; Even if it were ever someday universally embraced it could, for Gregg, be no more than a contingent universal. Gregg's deepest commitments, for example to 'the prevention of suffering', can have the backing of nothing more than a 'weak ontology'69, and this provides a poor basis for critique and, where necessary, for 'condemnation' ${ }^{70}$ 
Forst, by contrast, seeks to justify a conception of human rights which retains the essential sense of them 'as individual rights no human being can have good reasons for withholding from others ${ }^{\text {}} 71$, and to do so on robust grounds that are invulnerable to the charge that they are simply products of a particular tradition and applicable only to particular societies. He aims to provide a conception of right as 'interculturally nonrejectable, universally valid, and applicable in particular cases' ${ }^{72} \mathrm{He}$ wants to provide a persuasive rational account of human rights that does not rely on contestable assumptions such as those that underpin the various traditions of natural rights.

Morality for Forst is autonomous: 'based neither on laws of God or a secular sovereign, nor on the unquestioned values of an established form of life'. ${ }^{73}$ Given his critical orientation he rejects the classical, theological and metaphysical, foundations even more firmly than Gregg's pragmatic social constructionist approach allows. On Forst's view the classic foundations of morality have, historically, all too often led to authoritarian thinking and oppressive social orders. Resistance requires critique that can reveal such 'foundations' as groundless, unjustifiable to free and equal persons with the right to resist such authoritarian assumptions' ${ }^{74}$ In claiming such rights and rejecting the claims of authorities which cannot be freely justified, people affirm their autonomy and their own normative authority, against heteronomy. As we have seen, dissensus may draw on the language and authority of human rights. One authority may come to replace another, but there is a structure to the subversive claim, to Forst's conception of dissensus, that transcends any particular authority, that is, the claim of a right: "not to be ruled without justification"75; A claim that can be reconstructed as nothing other than a claim to non-authoritarian 'self-authorship'. ${ }^{76}$ For Forst, reason, understood as 'the faculty of criticising bad justifications and of instead offering justifications that could possibly hold among free and equal persons, ${ }^{77}$ is fundamental to critique, and to the logic of dissensus.

Forst's 'anti-foundationalist foundationalism"78 carries no substantive claims other than that we have a right to criticise any substantive normative arrangements; a right to justification realised in the demand that there be no social relations that cannot be appropriately justified to those who are subject to them. He insists that we should affirm the "fundamental truth" ${ }^{79}$ of our conviction of the injustice of certain things, including slavery and human exploitation, and insists that the fundamental claim of human dignity, to be respected as an equal normative authority, an equal agent of justification, cannot be relativised: 'The 'No' to a dictator is not an 
invitation to embrace an exemplary or attractive ontology; it is the affirmation of a nondeniable moral claim' ${ }^{80}$

In justifying the right to justification, Forst ultimately turns from Kant to Levinas. He argues that the reason we owe reasons, the ground of moral obligation, does not ultimately lie as Kant argues in self-reflective appeal to our dignity as reasoning persons. Rather, morality is, fundamentally concerned with the dignity, finitude, and vulnerability of other human beings: 'Their 'face' - to use Levinas's image - is what calls one to an awareness of the duty to justify'. ${ }^{81}$ We have a duty to justify simply by virtue of our humanity, which is at the same time always fellow humanity, it is a duty cognised through moral insight and recognised in the free acceptance of responsibility. No deeper justification of the right to justification is available or needed, and those who demand something more have essentially 'missed the point of morality'. 82

One might object that the appeal to insight into the responsibility that one owes to persons, as such, might seem to rest on some metaphysical conception of the moral person. Forst rejects any such suggestion and insists that it is an insight of thoroughly practical reason that reveals itself to any 'reasonable' person with eyes to see: 'To put it in Heideggerian terms, it is a mode of being-in-the-world that lets others appear in light of the principle of justification'. ${ }^{83}$ Ultimately, Forst and Gregg seem to agree that morality is not given to us by some otherworldly authority, whether theological or metaphysical. It is entirely a thing of our practical world, our human being, our reality and reason. We achieve it in the cognition and recognition of our original responsibility to finite others; a responsibility to treat others as equal agents of justification. It originates in our insight into this responsibility to justify, and there is nothing metaphysical or mysterious about it: 'for this being responsible simply is our basic way of being in the world as finite beings who use reasons, that is, who can give reasons and who demand them of others'. ${ }^{84}$ Morality is just this 'being responsible' in the context of a community of justification and responsibility that includes all of humanity.

\section{Seeking Foundations in Gregg}

Forst accounts for the normativity of a basic right to justification in terms of our nature as rational, and finite social animals, capable of cognising and recognising an 'original ought' ${ }^{85}$ Gregg, on the other hand, claims that human nature 'entails nothing normative" ${ }^{86}$, insisting that 
we cannot derive an 'ought' form an 'is'. As we set out below, however, at least implicit traces of recognition of an original responsibility can be found in Gregg's work.

Gregg tells us that he does not believe that a commitment to human rights needs to be founded in anything more than 'an intuition about justice, an interest in justice, a motivation to do justice'. ${ }^{87}$ We read this statement as indicating that Gregg's commitment to human rights is grounded in his sense, his cognition and recognition, that human beings are entitled to be treated with a certain moral respect. The commitment, starting out, is not to a particular list of human rights but to the bare idea of human rights, that is to the idea that human beings are entitled to decide together upon and embrace a conception of the basic entitlements, rights, that an individual ought to have. Gregg seems to be committed to a basic right to self-authorship; effectively a right of political inclusion in the creative processes by which we decide the conditions of our living together. That right, of each and every human being, rests on our equality: 'as individuals capable of assigning themselves human rights' ${ }^{88}$ This capacity for self-authorship ${ }^{89}$, which Gregg sees us as sharing, is clearly associated with aspects of the human condition and in particular with our natality. We come back then to Arendt's claims concerning our equality and the previously discussed, supervenience of that claim on our natality. In Arendt we have natality as unacknowledged foundation of a commitment to equality and the ground of our political capacity. In Gregg we find natality, expressed in the capacity for self-authorship, as unacknowledged ground of our equal right to participation in the authoring of rights.

We now want to identify universal commitments in Gregg's position which are compatible with the commitment to practical reason we previously outlined in Forst's work. We suggest that a recognition of those commitments and their implications would allow Gregg to reformulate his position and find a more satisfying reconciliation of particularity and universality in an understanding of 'reason and justice as 'situated' yet critical and transcendent with regard to concrete contexts' ${ }^{90}$

Where in Forst we find commitment to a universal human right to justification as transcendent foundation for the construction of a just society, Gregg insists that we can have no entirely stable point outside politics: 'In this sense, human rights are never above politics; they are not 'higher principles' against which contending 'lower principles' might be judged' ${ }^{91}$ In Gregg we have a version of immanent critique, which leaves us asking why and when we should appeal to the immanent standards and by what criterion we should evaluate those 
standards. In answer to the question why we should appeal to our community's standards, and in particular its conception of human rights, to motivate criticism of our own society and intervention in others, Gregg turns to the transcendent and fundamental value, that is effectively for Gregg the universal value, of the prevention of suffering: 'the prevention of suffering is a fundamental good that trumps competing goods'.92

In considering the evaluation of standards and the establishment of universal minimal moral standards in the form of thinly conceived human rights ${ }^{93}$, Gregg seems to take inspiration from Walzer's 'reiterative universalism'. The universal standards on this view are established from the bottom-up moving from thick to thin: 'We might best think of them not as discovered or invented but rather as emergent' ${ }^{94}$ They emerge as external criteria for the criticism of any society and its particular standards from the particular standards of various communities through a reiterative process. As previously explained, Gregg sees the standards emerging here as ideally 'universal' in just the empirical sense of being shared by all. When turning to the issue of how we might properly 'determine what should count as a human right', Gregg starts by proposing, as a necessary but not sufficient condition, that a valid candidate norm should be able to 'find free embrace by its addressees' ${ }^{95}$ A free embrace needs to be justified 'on publicly acceptable reasons capable of freely persuading participants in public discussion' ${ }^{96}$ Forst would agree with Gregg that those who are subject to norms should be the final arbiters of their validity. Forst would of course go further and claim that 'they have a right to be such judges" ${ }^{\text {'97}}$; they have a right to justification. This is the kind of claim that Gregg would be inclined to insist is not 'immediately defensible'. Nevertheless, the fact that he consistently attributes normative authority to the addressees of norms, without relativising the claim, suggests that for him it is, at least implicitly, a universal; a real moral universal for any human beings anywhere.

Gregg argues that the strength of the validity of any moral norm, or human right will depend on the nature of the processes through which it was established. He warns of the importance of ensuring that 'communication is not systematically distorted' ${ }^{98}$ Again, Forst would agree with Gregg that we need processes and practices of justification that are capable of challenging systematically distorted communication, and 'overcoming false justificatory reifications' ${ }^{99}$ This, of course, is just what critical theory aims to do, and for Forst an effective critical theory must be 'based on the principle of critique itself, as the principle of justification'. ${ }^{100}$ We suggest that the unpacking of Gregg's claim according to which a valid moral norm must be freely embraceable by those affected on the basis of acceptable reasons in 
a situation of undistorted communication, leads quickly back to the principle of justification. Moreover, given the nature of human rights claims and the general requirements of practical reason, it leads back to the conclusion that the validity of a moral norm depends on no one having good, reciprocal and general, reasons for rejecting it.

Gregg denies that there are any foundations to morality and human rights beyond the particular community that enacts them in explicit claims and law. However, it seems to us that he - implicitly at least - cognises, and perhaps recognises, a deeper ground for moral responsibility and consistently adopts what we might appreciate as the moral point of view. That is a view that reflects the transcendental right to respect and justification of every person, everywhere. A moral point of view rests on 'the insight that human beings as vulnerable and finite beings require moral respect and thus justifying reasons; and in this sense this is not a morality for mere 'rational beings' but for those who have a sense of the evils that follow from denying someone's right to justification and not being respected as an author and addressee of

validity claims' ${ }^{101}$ Gregg seems to have such a sense and the avoidance of such evils is surely the 'desired result' that his pragmatism is directed towards. ${ }^{102}$

\section{Conclusion - Recovering the moral context}

The difficulties with Gregg's project originate with his commitment to a resolutely political constructionism. The indispensable moral principle of justification, on the basis of which we can proceed with morally guided political construction, is not itself constructed but is reconstructed through analysis of the normative world into which we are thrown as human beings. The ground of this obligation to give justifications is the unconditional demand for respect which the humanity of other persons places on us. It is grasped as a matter of 'moral insight' and accepted, when it is, as 'a responsibility that one simply has as a human being and that need not, and cannot, be further justified among human beings'. ${ }^{103}$

Gregg does not share this 'moral insight', or more accurately, in our view, he at some level cognises it, but seems to sets himself against giving it explicit recognition. He presents a variety of 'moral localism'104, in terms of which responsibility and the duty to justify is always constructed in particular contexts, particular ethical and political communities. There is no room in Gregg's project for 'morality' as the 'idea that human beings as members of the in principle unrestricted community of moral persons unconditionally owe one another a basic 
form of respect and justification for their actions, no matter how united or divided they are in reality, and whatever conceptions of the good, the worthwhile, and of happiness they have'. ${ }^{105}$

Yet, without morality, and the moral principle of justification, we lack a strong foundation for critique of the political and ethical constructions and processes of construction we find around us in real nation states and in transnational contexts. Gregg's notion of the human rights state, as we see it, appears to be an attempt to compensate for his exclusion of the moral, by providing a point external to the normative order of the nation state from which they can be criticised. The effort seems to us to be flawed and to offer only weak ground for the staging of dissensus and condemnation of unjustifiable political constructions. The human rights states are themselves constructions and constructed mainly by participants in the associated nation states, human rights advocates and 'like-minded political confrères' ${ }^{106}$ The risk of ideological capture is obvious.

Gregg seems to understand himself to be offering a 'normative vision for nonhegemonic global politics'. ${ }^{107}$ We see his project as aiming for the development of counter-hegemonies. We have two primary concerns. Firstly, the ideas of human rights and especially a minimalist vision of human rights, such as Gregg's, already seem to be an integral part of the existing dominant hegemony of postmodern capitalism. Costas Douzinas, for example, rhetorically asks whether human rights are now anything more than 'the ideological gloss' on the empire of capital. ${ }^{108}$

Secondly, Gregg's universalistic vision, if it ever approached accomplishment, would constitute a new dominant hegemony, and not necessarily an entirely benevolent one. The vision seems to leave little room for the subsequent emergence or staging of dissensus. What seems to be offered is a totalizing cosmopolitan vision of human rights universally affirmed. Because the project is grounded in affirmation rather than critique, it is not clear where the impetus for dissensus ever really originates; there is construction with no outside and no subversive moment. It is not clear that this cosmopolitan project would actually challenge injustice and, in particular, the injustices of the neo-liberal consensus and its individualizing and commodifying ideology of rights. The work of Wendy Brown ${ }^{109}$ gives eloquent warning of the dangers of any insufficiently critical affirmation human rights.

We want to end by briefly reflecting on the practical need to recover the moral context of human rights for business in a time when globalisation makes it increasingly difficult for states 
to control the impacts of corporations on human rights through law. The support given by the United Nations to the work of John Ruggie endorses the view that an effective response to the governance gaps which have emerged in recent decades must directly engage business at the moral level. The Guiding Principles ${ }^{110}$ developed by John Ruggie identify corporate responsibilities, beyond law, to 'respect' human rights in their daily operations. Thus, the Guiding Principles are clearly an attempt to overcome the limits of statism and legalism. The focus of the Ruggie initiative is to encourage corporations to act on a moral responsibility to respect human rights, by instituting processes of due diligence and accountability that enable the corporation to have assurance that it is not treating individuals or groups in ways that cannot be justified. As we have explained above, morally competent responsible individuals, cognising and recognising the moral context of their action, will appreciate that adequate justifications need to meet the criteria of reciprocity and generality. Part of the challenge for corporations is to implement adequate processes of justification, for the testing of norms and actions, in complicated and extended business networks.

Ruggie's emphasis is thoroughly pragmatic: his interest is not on the laying out of philosophical foundations but in helping business to recognise and respond to its responsibility, and to engage existing capacities and expertise for due diligence and accountability; to ensure effective management of corporate respect for human rights. We find a similar commitment to pragmatism in Gregg's project, and a similar desire to overcome the limitations of the nation states. However, in our view, Gregg allows his theoretical commitments to get in the way of a proper engagement with the moral context. With the idea of the 'human rights state' Gregg seems to be imaginatively generating a substitute for the moral, a source of non-state-based rights that can stand as a critical provocation to the nation state and lead the development of law, and positive rights, in real nation states. However, his resolutely political stance prevents him from adequately engaging with the essential source of the category of non-state-based rights, that is, the moral itself. It leads him back to statism and legalism, and inclines him to insist that if they are to have practical purchase human rights need to find recognition in a real nation state and in law.

We of course recognise the power of law, and appreciate the value of inscribing advances of human rights in law. Nevertheless, we do insist that rights can provide powerful reasons for action ahead of their incorporation in law, and in fact quite aside from law. Because right have found a place in the public space of normative reason, they offer a particular kind of reason for 
action, justification, and carry the 'power of justifications'. ${ }^{111}$ Gregg's human rights state offers us a new way of thinking about that space of justifications, and how it might be developed. We find the image stimulating and it seems to us that it can provide communities in various contexts with a metaphorical model for working out the nature and meaning of human rights in their particular situation. That work, for us, must be grounded in respect for the universal right to justification.

The UN Guiding Principles have been given wide endorsement by business and by states. However, the real challenge lies with the implementation of the principles by corporations in situations where respect for human rights may significantly reduce profit. Nowhere in the formal reports leading to the Guiding Principles, does Ruggie explicitly justify his recommendations by arguing that corporations have a moral responsibility to respect human rights that should be recognised as such. Only in the final stage of the development of the Guiding Principles does the justification shift from reliance on 'enlightened self-interest' to what is to 'all intents and purposes' ${ }^{112}$ a moral justification, and recognition that corporate due diligence 'must go beyond simply identifying and managing material risks to the company itself to include the risks a company's activities and associated relationships may pose to the rights of affected individuals and communities. ${ }^{113}$ If managers are to effectively implement the Guiding Principles even at real cost to their corporations, they must have means of justifying their actions. Managers and directors are 'accountable', and they must be able to discharge that duty: 'their decisions must be capable of being justified to their shareholders if they are to be seen and accepted as a legitimate exercise of their responsibilities. ${ }^{114}$ A hesitancy in making the moral dimension of corporate responsibility for human rights explicit, is understandable in a normative climate where managerial responsibility to investors has for generations been given primacy. There is, arguably, some need in certain jurisdictions for change in the legal responsibilities of managers and directors, but there is a greater need for change in the broader normative framework within which business operates.

Extending the Gregg's conception of the human rights state, to business communities and corporations, has potential to help reform the space of justifications and accountability, within which corporate managers operate. We suggest that we can usefully take Gregg's ideas, developed in relation to the human rights state, and apply them 'where the action is ${ }^{\text {'15, }}$, that is, where it is in an age where corporate power tests and sometimes exceeds the capacities of state control. Gregg's ideas can fit well with what seems to be the new world of networked ${ }^{116}$ and 
collaborative $^{117}$ governance and disaggregated sovereignty. ${ }^{118}$ The human rights business community and the human rights corporation can become rhetorical devices for carrying the recognition of moral responsibility for human rights into business culture. In such open communities of 'advocates', including those whose lives and rights are adversely affected by corporate activity, claims may be raised and tested, justified, in much the way that Gregg suggests. Such activity may reshape expectations against which managers in particular corporations hold themselves to account. As Gregg suggests work will be needed, by these communities, to develop and protect spaces in which rights claims can be raised and recognised, and especially to give recognition to the interests of those whose voices tend not to be clearly heard by business. Business itself must take primary moral responsibility for respecting human rights, but there needs to be a way of keeping the dissensual moment alive: Here Gregg's idea of a community separated from itself challenging itself to progress in its respect for human rights is truly inspiring.

\section{Acknowledgements}

The authors would like to acknowledge the support given by the editors of this special issue during our development of this paper. We are grateful for the detailed and generous advice given by René Wolfsteller, and for the inspiration provided by Benjamin Gregg.

\section{Disclosure statements}

No potential conflict of interests was reported by the authors.

\section{Notes on contributors}

Yingru Li is completing a $\mathrm{PhD}$ in Accounting at University of Glasgow. Her main research interests are accountability, social justice and human rights in business

John McKernan holds a PhD in psychology from University of Glasgow. John is Professor of accounting and the head of accounting and finance subject group in the Adam Smith Business School at the University of Glasgow. His main research interests are accountability, business ethics, and human rights in business. 
1. Benjamin Gregg, The Human Rights State: Justice within and Beyond Sovereign Nations, (Pennsylvania: University of Pennsylvania Press, 2016).

2. Ibid, 42.

3. Rainer Forst, 'A Critical Theory of Politics Grounds, Method and Aims. Reply to Simone Chambers, Stephen White and Lea Ypi', Philosophy \& Social Criticism 41, no. 3 (2015): 227.

4. Benjamin Gregg, The Human Rights State, 16.

5. Ibid, 3.

6. Ibid, 11.

7. John Tasioulas. 'Human Rights, No Dogmas: The UN Guiding Principles on Business and Human Rights. Available at SSRN: https://ssrn.com/abstract=2561420, (2015): 1.

8. John Gerard Ruggie, Just Business: Multinational Corporations and Human Rights (Norton Global Ethics Series) (New York: WW Norton \& Company, 2013).

9. Ibid, 2

10. Ibid, 11.

11. Benjamin Gregg, Human Rights as Social Construction, (Cambridge: Cambridge University Press, 2011), 27.

12. Ibid, 232.

13. Richard Rorty, Objectivity, Relativism, and Truth (Cambridge: Cambridge University Press, 1991), 200; Benjamin Gregg, Human Rights as Social Construction, 232.

14. Benjamin Gregg, Human Rights as Social Construction, 107.

15. Hannah Arendt, The Origins of Totalitarianism (Boston: Houghton Mifflin Harcourt, 1968), 301.

16. Seyla Benhabib, The Reluctant Modernism of Hannah Arendt, (Lanham: Rowman \& Littlefield Publishers, 2003), 193.

17. Seyla Benhabib, The Reluctant Modernism of Hannah Arendt, 195.

18. Ibid.

19. Jeremy Waldron, 'Arendt on the Foundations of Equality' in Politics in dark times: Encounters with Hannah Arendt, ed. S. Benhabib, (Cambridge: Cambridge University Press, 2010), 20.

20. Jeremy Waldron, 'Arendt on the Foundations of Equality', 37.

21. Jeremy Waldron, 'Arendt on the Foundations of Equality', 38.

22. Hannah Arendt, Origins of Totalitarianism, 296.

23. Frank Michelman, 'Parsing 'a right to have rights', Constellations 3, no. 2 (1996): 207.

24. Ibid.

25. Seyla Benhabib, The Reluctant Modernism of Hannah Arendt, 185.

26. Hannah Arendt, Imperialism: Part Two of the Origins of Totalitarianism, (Boston: Houghton Mifflin Harcourt, 1968), 298.

27. Ibid, 219.

28. Benjamin Gregg, The Human Rights State, 48.

29. Ibid, 33.

30. Ibid, 14.

31. Ibid, 227.

32. Ibid, 47.

33. Jacques Ranciere, Dissensus: On politics and aesthetics, trans. S. Corcoran (New York: Continuum International Publishing Group, 2010), 70. 
34. Ibid, 71.

35. Ibid, 68.

36. Jacques Rancière, 'Politics, identification, and subjectivization', October 61 (1992): 60.

37. Ibid, 73.

38. Ibid, 59.

39. Benjamin Gregg, The Human Rights State, 224.

40. James Ingram, 'Cosmopolitanism from below: Universalism as contestation', Critical Horizons 17, no. 1 (2016): 74.

41. Jacques Ranciere, Dissensus: On politics and aesthetics, 70.

42. James Ingram, 'Cosmopolitanism from below: Universalism as contestation, 74.

43. Jacques Ranciere, Dissensus: On politics and aesthetics, 68; Benjamin Gregg, The Human Rights State, 23.

44. Benjamin Gregg, The Human Rights State, 23

45. James Ingram, 'The Revolutionary Origins of Human Rights: History, Politics, Practice', Journal for Human Rights/Zeitschrift für Menschenrechte 9, no. 1 (2015): 21.

46. Ibid, 3 .

47. Jacques Rancière, Disagreement: Politics and Philosophy (Minneapolis: University of Minnesota Press, 1999).

48. Rainer Forst, The right to justification: Elements of a constructivist theory of justice (New York: Columbia University Press, 2012), 2.

49. Frank Michelman, 'Parsing 'a right to have rights', Constellations 3, no. 2 (1996): 205.

50. Rainer Forst, 'The Justification of Human Rights and the Basic Right to Justification: A Reflexive Approach', Ethics 120, no. 4 (2010): 730.

51. Rainer Forst, The right to justification, 2.

52. Rainer Forst, The right to justification, 205.

53. Ibid, 209-210.

54. Ibid.

55. George Mead, Mind, Self, and Society (Chicago: University of Chicago Press, 1934, 1967).

56. Benjamin Gregg, Human Rights as Social Construction, 78.

57. Benjamin Gregg, Human Rights as Social Construction, 79.

58. Ibid, 78.

59. Rainer Forst, 'A Critical Theory of Politics Grounds, Method and Aims', 226.

60. Rainer Forst, The right to justification, 5.

61. Rainer Forst, The right to justification, 5.

62. Ibid.

63. Ibid, 18.

64. Ibid, 19.

65. Ibid, 2.

66. Jacques Ranciere, Dissensus: On politics and aesthetics, 70; Rainer Forst, The right to justification, 2.

67. Jacques Rancière, Disagreement: Politics and Philosophy, 17.

68. Benjamin Gregg, The Human Rights State, 89.

69. Stephen White, Sustaining affirmation: The strengths of weak ontology in political theory (Princeton University Press, 2000).

70. Jodi Dean, 'The Politics of Avoidance: The Limits of Weak Ontology', Hedgehog Review 7, no. 2 (2005).

71. Rainer Forst, The right to justification, 204.

72. Ibid, 204.

73. Ibid, 45 . 
74. Rainer Forst, 'A Critical Theory of Politics Grounds, Method and Aims', 227.

75. Ibid, 227.

76. Benjamin Gregg, The Human Rights State, 27-28, 125.

77. Rainer Forst, 'A Critical Theory of Politics Grounds, Method and Aims', 228.

78. Ibid, 227.

79. Ibid.

80. Ibid, 229

81. Rainer Forst, The right to justification, 36.

82. Ibid, 55.

83. Ibid, 60 .

84. Ibid, 61.

85. Ibid, 61.

86. Benjamin Gregg, The Human Rights State, 5.

87. Ibid, 11.

88. Ibid, 68.

89. Ibid, 10.

90. Ibid, 139.

91. Benjamin Gregg, Human Rights as Social Constructions, 27.

92. Benjamin Gregg, The Human Rights State, 198.

93. Benjamin Gregg, Thick Moralities, Thin Politics. Social Integration across Communities of Belief (Durham: Duke University Press, 2003); Benjamin Gregg, Human Rights as Social Construction, 72.

94. Michael Walzer, Interpretation and social criticism (Cambridge: Harvard University Press, 1993), 23.

95. Benjamin Gregg, The Human Rights State, 175.

96. Ibid, 17.

97. Rainer Forst, 'A Critical Theory of Politics Grounds, Method and Aims', 229.

98. Benjamin Gregg, The Human Rights State, 176.

99. Rainer Forst, 'A Critical Theory of Politics Grounds, Method and Aims', 229.

100. Ibid.

101. Rainer Forst, The right to justification, 39.

102. Benjamin Gregg, The Human Rights State, 11.

103. Rainer Forst, The right to justification, 55.

104. Benjamin Gregg, The Human Rights State, 89.

105. Rainer Forst, The right to justification, 63.

106. Benjamin Gregg, The Human Rights State, 46.

107. Ibid, 39.

108. Costas Douzinas, Human rights and empire: the political philosophy of cosmopolitanism (London: Routledge, 2007), 7.

109. Wendy Brown, States of injury: Power and freedom in late modernity (Princeton: Princeton University Press, 1995).

110. United Nations Human Rights Council (UN), (2011), 'Guiding Principles on Business and Human Rights: Implementing the United Nations 'Protect, Respect and Remedy' Framework', UN Doc. A/HRC/17/31, available at:

http://www.ohchr.org/Documents/Publications/GuidingPrinciplesBusinessHR_EN.pdf.

111. Rainer, Forst. 'Noumenal power', Journal of Political Philosophy 23, no. 2 (2015): 112.

112. Wesley Cragg. 'Ethics, enlightened self-interest, and the corporate responsibility to respect human rights: A critical look at the justificatory foundations of the UN framework', Business Ethics Quarterly 22, no. 1 (2012): 9-36, 25. 
113. United Nations Human Rights Council (UN), (2010), 'Business and Human Rights: Further Steps Toward the Operationalization of the 'Protect, Respect and Remedy' Framework'. UN Doc. A/HRC/14/27, para. 81, available at: http://www2.ohchr.org/english/issues/trans_corporations/docs/A-HRC-14-27.pdf

114. Ibid, para. 15.

115. Gerald A Cohen, 'Where the action is: On the site of distributive justice', Philosophy \& Public Affairs 26, no. 1 (1997): 3-30.

116. John Braithwaite, 'Responsive regulation and developing economies', World Development 34, no. 5 (2006): 884-898.

117. Andreas Rasche, 'Collaborative Governance 2.0', Corporate Governance: The international journal of business in society 10, no. 4 (2010): 500-511.

118. Anne-Marie Slaughter, 'Disaggregated sovereignty: Towards the public accountability of global government networks', Government and Opposition 39, no. 2, (2004): 159-190. 